\title{
Sites of Resistance: LGBTQI+ Experiences at Trinity Western University
}

\section{Heather Shipley(i)}

\begin{abstract}
Trinity Western University's Community Covenant has been the subject of public and legal attention with specific reference to a proposed law school. At the heart of much of the contention about the law school, opponents have expressed concern about the provisions in the Covenant that restrict the rights of LGBTQI+ students - their identities and relationships. While much of the focus has been on the potential harm for LGBTQI+ students, and the expectation that law schools uphold Charter values - the voices of queer students and allies have largely been sidelined. This article offers space for LGBTQI+ students, staff and allies to discuss their lived experiences of sexual diversity and the harm facing the queer community at Trinity Western University. As they state, the Covenant is only a part of the issue; the culture it supports is what needs to change.
\end{abstract}

Keywords: LGBTQI+, equality, religious freedom, harm, diversity, Trinity Western University

\section{Résumé}

L'Université Trinity Western a fait l'objet d'une attention publique et juridique pour son convenant obligatoire. Au cœur d'une grande partie de la controverse entourant la faculté de droit se retrouvaient les préoccupations relatives aux dispositions de ce covenant, qui restreignent les droits des étudiants LGBTQI+ ainsi que leur identité et leurs relations. Les opposants ont majoritairement mis l'accent sur les préjudices potentiels pour les étudiants LGBTQI+ et sur l'exigence que les facultés de droit respectent les valeurs promues par la Charte. Les voix des étudiants queers et de leurs alliés furent, quant à elles, largement mises de côté. Cet article offre donc un espace pour les étudiants, le personnel et les alliés LGBTQI+ afin de discuter de leurs expériences vécues en matière de diversité sexuelle et les préjudices auxquels fait face la communauté queer au sein de l'Université Trinity Western. Comme ils l'affirment, le covenant n'est qu'une partie du problème; la culture qu'il soutient est ce qui doit changer.

Mots clés : LGBTQI+, égalité, liberté religieuse, préjudice, diversité, Université Trinity Western 


\section{Introduction}

"Why do gay students even go to Trinity Western?"

That question has been posed, in different ways, across multiple spaces, during both the current and past legal disputes about Trinity Western University's Community Covenant. Embedded in this question is the assumption of a binary and conflictual relationship between religion and sexual diversity - that gay students wouldn't also be religious. This was made explicit in a statement from the 2001 Supreme Court of Canada decision about Trinity Western's education program: that "a homosexual student would not be tempted to apply for admission...TWU is not for everybody; it is designed to address the needs of people who share a number of religious convictions" (TWU 2001 at para 25). The sense that outsiders can determine whether or not an LGBTQI+ ${ }^{1}$ individual should attend Trinity Western relies on these pervasive misunderstandings about the relationship of religion to sexual diversity and on privileged assumptions about equal access to schooling.

While LGBTQI+ students (and to a lesser degree, faculty and staff) have been in the eye of the storm as the debate and legal disputes about Trinity Western have gathered in the last several years, this article is not a legal analysis of the issues at play. This paper is a space for LGBTQI+ students and staff, current and former, of Trinity Western University to reflect on the issues that permeate the current debates, including the Community Covenant, the law school, and the experiences of LGBTQI+ individuals at Trinity Western University. I discuss the former and current legal decisions regarding Trinity Western and its Community Covenant to contextualize the interviews I conducted with LGBTQI+ students and staff about the experience of sexual diversity on campus. There are a number of significant issues raised by the participants of this study. This article brings light to the concerns and realities as they were presented to me. However, there is much more to reflect on in more depth on each thematic analysis.

Personal narratives have been the inspiration for much of the advocacy done to secure rights, achieve rights, and enforce rights for minority identities and groups. I am often struck by the use of personal narrative in academic work to challenge assumptions and break down barriers. These narratives offer us a window into the spaces of systemic disadvantage beyond clinical analysis. They contextualize and locate the theoretical. They flesh out the nuance of issues in ways that legal and academic analysis cannot. And they remind us that the personal is always already political. There are a lot of reasons gay students go to Trinity Western. The interviews I present here offer some of those reasons. But ultimately, the question

Recognizing that this acronym does not capture all the nuance of sexual and gender diversity, it is the acronym that was suggested to me by the student co-facilitator of the OneTWU Facebook group when I was developing my recruitment documents. The + acknowledges identities not yet captured, not yet known, and allies. In this article, I use the acronym LGBTQI+ which stands for lesbian, gay, bisexual, trans, queer, and intersexed; the + opens space for allies and sexual identities not encompassed by the acronym itself. Although many legal cases in Canada do not attend to this breadth of sexually diverse identities and although both opponents and proponents of the law school use different acronyms in their own written submissions or public statements, the implications of provisions within the Community Covenant extend beyond lesbian and gay individuals and relationships. 
isn't why gay students go to Trinity Western. Gay (LGBTQI+) students are at Trinity Western. The question is, "what kind of treatment should they expect at Trinity Western?" This article offers space for the personal narratives of current and former members of the Trinity Western University community, allowing them to share in their own voices what they think of the Covenant and the law school and to reflect on LGBTQI+ rights and identities in the face of these debates.

\section{A Bit of Background}

In 2012, Trinity Western University submitted a proposal to the Federated Law Societies of Canada [FLSC] for a law school they intended to open in September 2016. The law school was approved by the FLSC and by the British Columbia Minister of Education. Consent for the law school was revoked by the B.C. education minister as of December 2014, after the BC Law Society voted against accrediting Trinity Western students. After three provincial decisions regarding accreditation (in Ontario, Nova Scotia, and British Columbia) the case was heard at the Supreme Court of Canada (SCC) in 2017, ${ }^{2}$ and the decisions rendered by the SCC in June 2018 regarding both the Law Society of British Columbia (LSBC) and the Law Society of Ontario held that their refusal of accreditation was reasonable ( $L S B C$ 2018; TWU 2018).

These decisions mark a shift in the framing of LGBTQ $^{3}$ rights, in particular the reasonable limits placed on religious freedom to protect LGBTQ rights. In August 2018, Trinity Western announced that it would no longer require students to sign the Community Covenant (Stueck 2018). ${ }^{4}$ While striking down the requirement to sign the Covenant signifies an important change in the obligations made on Trinity Western students, there are reasons to be cautious about overstating what this change addresses, as articulated by former Trinity Western student Matthew Wigmore: "I think the core thing to understand is that this is not a change in the covenant, it is simply a change in the requirement to sign it. Let's celebrate this as a first step but nothing more-to do so would undermine the mounds of work that need to be done to respect LGBTQ students on campus" (Stueck 2018).

The SCC decisions in 2018 point to a new direction in the acknowledgement of rights and protections for the sexually diverse, but the decisions do not respond to concerns about current or future LGBQTI+ students (or faculty or staff) at Trinity Western regarding their experiences on campus. Legal decision making has been the subject of critique regarding multiple and varied aspects of the decisions themselves (Johnson 2007; Mathen 2008; Berger 2015; Beaman 2012; Shipley 2015), including critiques of legal decisions about Trinity Western (Craig 2013; Mathen and Plaxton 2014; Kislowicz 2016; Bussey 2018; Berger 2015, among others).

2 The initial decision by Justice Wagner denying participation was subsequently, and unusually, modified via a "varied" order by Chief Justice McLachlan permitting twenty-six groups to intervene, including LGBTQ groups (https://www.thestar.com/news/gta/2017/08/01/supremecourt-reversal-allows-lgbtq-groups-to-take-part-in-case-involving-bc-christian-university.html).

3 This is the acronym used by the Supreme Court of Canada; while they do not actually unpack or explain it, it is notably the first usage of this acronym by the SCC.

4 It is not yet clear whether that includes only current and future students at Trinity Western or whether the previous Covenants that have been signed by students will be destroyed. 
Opponents of the law school have pointed to Trinity Western's Community Covenant as exclusionary and discriminatory towards LGBTQI+ individuals. The Covenant is one of several public statements of faith for members of the university community. It is described by Trinity Western as a "solemn pledge" undertaken by faculty, staff, and students and includes, along with a statement of values and a definition of the Christian community, a set of requirements for community life at Trinity Western University. Among these guidelines, faculty, staff, and students have been required to abstain from, among other things, "sexual intimacy that violates the sacredness of marriage between a man and a woman." 5

It is this particular requirement that was central to much of the opposition to the law school at Trinity Western University. The requirement for students to either deny their LGBTQI+ identities or be rejected from admission to the school was seen as a violation of the Canadian Charter of Rights and Freedoms, as contradictory to the core principles of legal education in Canada (particularly regarding principles of social justice and equality), and as explicitly discriminatory toward LGBTQI+ individuals, who are historically disadvantaged in Canada (and elsewhere).

Although concerns about the experiences of LGBTQI+ students have come to the forefront of the debate about the Covenant and the proposed law school, a lot of the space given to express these concerns has been taken up by individuals who are not themselves LGBTQI+ students, faculty, or staff (current or former) at Trinity Western University. While my initial research project (2013-2014) ${ }^{6}$ was borne out of the law school controversy, the core issues raised in the current set of interviews (2017-2018) were not about the law school itself. They are reflective of pervasive issues of campus sexual violence across university campuses, faith-based or not. Participants in this study have pointed to the ways the Covenant further disadvantages students who experience sexual violence and are clear that revising the Covenant is only one aspect of the issue-campus culture is a much more engrained challenge. As stated by Matthew Wigmore already, there is much work still to be done to respect LGBTQI+ individuals on campus, the Covenant having only ever been one part of the issue.

There are complex legal questions on the table regarding religious freedom, equality for sexual minorities, and the requirements of law schools (regardless of their institutional identity) to uphold Charter rights and principles of social justice. The Covenant itself was a key issue for the law societies in their refusal to recognize Trinity Western as an approved faculty of law. That being said, the LSBC and Trinity (Ontario) decisions (2018) do not weigh in on whether or not the Covenant is discriminatory for current or future Trinity Western community members, beyond the proposed law school—nor were they asked to. In the dissenting reasons,

5 See “Community Covenant," Trinity Western University, online: http://twu.ca/studenthandbook/ university-policies/community-covenant-agreement.html; this is from the student handbook; faculty and staff must also sign the Covenant once a year.

6 I interviewed proponents and opponents of the law school, within and external to Trinity Western University in 2013-2014 as an entry into the broader discussion about religious freedom and LGBTQI+ equality rights. 
Justices Brown and Côté identify the Covenant as protected by human rights legislation, stating: "The unequal access resulting from the Covenant is a function of accommodating religious freedom, which itself advances the public interest by promoting diversity in a liberal, pluralist society" ( $L S B C$ at 22).

The majority reasons take a decidedly different view of the role of the Covenant, identifying the study of law within an environment infused with religious beliefs as a preference, not a necessity, for spiritual growth ( $L S B C$ at 22). There is much to reflect on in the framing of religion as a preference, not a core aspect of identity, and these issues will likely continue to be argued in the public arena and before the courts. Within the context of this article, I am interested in providing space for voices and considerations which have been largely unheard within these debates.

\section{Religion and Sexual Diversity}

Notably in the last two decades, in Canada and internationally, religious attitudes and practices as they have been witnessed in the public sphere have become increasingly seen as a source of concern. Public religiosity, often as represented by minority religions, has generally been framed as adhering to a set of values that contradict "secular" values (frequently coded as "Canadian" values) (Lefebvre and Beaman 2014; Beaman 2012). Perceptions of minority religions often draw on media representations of controversies, violent events, and actions of particular groups, which become stand-ins for minority religions writ large (Knott, Poole, and Taira 2013). Public perceptions of religion and religiosity are influenced by the media coverage (Hoover 2006) of specific controversies within national contexts; in Canada this includes whether niqab-wearing Muslim women should be permitted to veil while giving testimony ( $R v N S$ 2012); where the line should be drawn between free speech and hate speech when it comes to the distribution of antihomosexual flyers (Saskatchewan $v$ Whatcott 2013); and whether permitting members of the Hutterite community to have drivers licenses without photos generates a risk to public safety (Alberta $v$ Hutterian Brethren 2009).

Frequently, in the debates that stem from legal challenges, religious identity is presented narrowly (as is its named "opponent"). The reasons for this narrow representation can to some extent be attributed to the requirements of a legal case themselves (Berger 2015); claimants must frame their argument as to why a specific (and often singular) aspect of their identity is threatened or harmed in a particular instance. This legal requirement, however, does not address the reality of identity experiences for individuals who experience multiple corresponding traits in everyday life. Further, individuals who identify across intersecting categories often appear before the court to address one identity characteristic; the overlay of other aspects of identity are therefore not articulated or transmitted (Crenshaw 1991, 2014). The transmission of the legal decision and the narration of identity characteristics (Ritivoi 2009) from a given decision correspondingly represent only a small picture of the complexity in a legal dispute. But those narrowed pictures become generalized when they move from the legal context to the space of public perception and debate (Shipley 2014b, 2015). 
As a result of contemporary debates, such as that surrounding the law school at Trinity Western University, the picture of evangelical Christianity that has been generated has been tied directly (and in some cases solely) to anti-LGBTQI+ ideologies. This representation is a result of statements made by members of Trinity Western advocating for the law school (Bussey 2018; Dueck 2018; Newman 2013) both in legal contexts and in media coverage and interviews. The framing of these particular evangelical Christian ideologies, however, is mistranslated into a larger discourse about religion, and Christianity, in general (Dueck 2018; Stueck 2018)).

While Trinity Western argued to keep the Covenant on grounds of religious freedom, thus pitting religion against LGBTQI+ rights, current research demonstrates that discriminatory attitudes towards LGBTQI+ communities are ongoing and pervasive and not tied solely to religious spaces or religious institutions (Aune, Sharma, and Vincett 2008; Shipley 2014a; Taylor and Peter 2011; Søndergaard 2012). Harm towards the sexually diverse is experienced across religious and secular spaces; an analysis of the ongoing experience of discrimination requires sustained research interests that remove the assumption of religious ideologies as the core problematic in order to address the ways that anti-LGBTQI+ attitudes persist, and in many cases are permitted. ${ }^{7}$ Here I point to the issues that are generated when LGBTQI+ individuals are not able to be open about their identities without fear of reprisal; the ripple effect of harm that this denial causes are substantial. I am, however, not suggesting here that "secular" universities are unequivocally safe spaces-in general or for LGBTQI+ community members.

\section{Project and Methodology}

I interviewed ten LGBTQI+ Trinity Western community members, ${ }^{8}$ current or former, about the law school, the Covenant and the public representation of religion and sexual diversity related to this debate. I conducted semi-structured interviews by phone or Skype with the research participants; they could elect to participate anonymously or to be named. ${ }^{9}$ Individuals who chose anonymity were assigned pseudonyms (indicated by the use of italics). This is a small sample of participants, which I would not state represents all experiences of the LGBTQI+ community at Trinity Western, though, as the participants themselves point out, it is a small campus and the LGBTQI+ community subsequently is also small. And certainly, as many of the participants acknowledge, the silencing effect of the Covenant also means that individuals who might self-identify as LGBTQI+ would

7 There is much research that points to the historical and contemporary harm done by religion and religious ideologies to sexual and gender diversity. But what is often overlooked as religion remains the focal point is the pervasive discrimination occurring in nonreligious/secular spaces. My argument is that we need to attend to the issue of discrimination not as generated by religion, but as generated by deeply rooted problematic ideologies that transcend religion/nonreligion.

$8 \quad$ This research project has been supported by a Queen's University Faculty Association grant (20172018).

9 I have begun adding in the option to be named in research projects in response to comments made by participants who feel their identities are erased by anonymity; some fought to claim their identities, and being assigned a pseudonym indicates the erasure of those identities and that work. 
not be willing to risk exposure by speaking about their experiences while still at Trinity Western. Two participants were current students at the time of the interview and both were extremely concerned about the possibility of being "found out" by the university administration.

These interviews demonstrate the critical need to move beyond textual analysis and the narrowed misrepresentations of the identities for whom any legal dispute is significantly meaningful. The participants in this study have demonstrated that the controversy as it has been represented by debates within media has missed the mark as to the experiences (and ongoing concerns) of individuals about sexual identity and sexual diversity on Trinity Western's campus. Serious concerns that LGBTQI+ students will be discriminated against-overtly or covertly-have been raised by opponents to the law school and Covenant, and opponents to the Covenant more generally. However, there are also significant concerns regarding sexual violence connected to the Covenant and the possibility of punishment resulting from reporting these instances of sexual violence; the reality is that LGBTQI+ individuals have nowhere "safe" to disclose or report harassment or violence connected to their sexual identities. Challenging identity assumptions and essentializations is a core component of the debate (Moon 2012; Bakht 2007; Beaman 2012), but what has emanated from these interviews is the need to focus on immediate concerns on campus today connected to the boundaries and restrictions placed on sexual identity on campus.

\section{Religion and Sexuality: Narrativity and Law}

Although sexual orientation protections, historically and in contemporary challenges, are also restricted by non-religious framings, ${ }^{10}$ the perception of the debates surrounding access to protections for sexual minorities frequently places religion as the singular source of anti-LGBTQI+ attitudes (Shipley 2015). There are reasons for this, including the brief list above of the ways that religious freedom and religious ideologies have challenged protections and rights for the sexually diverse in cases across Canada. And it is also true that most religious traditions have doctrinal codes that condemn homosexuality as sinful or immoral. However, it is also true that since the beginning of codified religion, practice and belief have not always been tied to doctrine for religious individuals (Avishai 2008; Ehrman 2003).

The narration of identities within a legal framework requires a particular narrowing of identities to create concise arguments as to the threat of harm in a given situation: what is under threat and by whom. For LGBTQI+ claims, this continually places claims based on sexual orientation on a binary of normative/ heterosexual and non-normative/LGBTQI+. These required framings then become transmitted in their essentialized form outside the legal context.

10 By this I mean policies that historically denied access to sexual minorities based on inability to procreate "naturally," perceptions about normalcy and deviance, and in the current trans identity bill, the position the government has taken equating trans identities with pedophilia and the possibility of harm to youth. These all share similar bases, which use particular constructions of normal and abnormal sexualities, but they are not inherently religious positions and are also supported by non-religious opponents to sexual diversity. 


\section{Identity Research: Context and Nuance Regarding Religious and Sexual Identities}

Within religious studies, a growing body of work detailing the complexity of religious identity demonstrates that religious practice and values are often influenced by multiple factors in an individual's life, including politics and family practices (McGuire 2008; Bramadat and Seljak 2008; Beyer 2008; Davie 2014). Many religious individuals negotiate personal values and conflicts within their religious tradition to create a complicated set of ideologies and identifications related to their own morals (Arweck and Nesbitt 2011; Young 2015). Although this multifaceted reality of religious experience is expected within the discipline of religious studies, often religious identities are essentialized and overgeneralized outside the study of religion (Hoover 2006; Knott, Poole, and Taira 2013). Much formative work that unravels these essentializations provides insight into how religious identities have always been personally constructed (Davie 2014; Ehrman 2003; McGuire 2008; Emon 2013) and further demonstrates that the increasing numbers of non-religious or spiritual-but-not-religious identifications are not necessarily disconnected entirely from religious values or practices (Day, Vincett, and Cotter 2013; Woodhead, Heelas, and Seel 2005).

Frequently, within these narrowed identity constructs, the relationship between identity categories (such as religion and sexual identity) becomes misrepresented and portrayed as only ever possessing one type of relationship to each other. In this case, the ways that religion (historically and in contemporary society) has sought to constrain and regulate sexuality is at the forefront of debates regarding equality rights and recognition for LGBTQI+ communities. The reasons for the general picture of religion as opposing or constraining sexual diversity are clear; in many cases, and across the globe, vocal opponents of sexual diversity, rights, and recognition (let alone fair and equal treatment) have sought to declare sexual diversity immoral and sinful and, in many cases, have proposed that nonheterosexuality is a "choice" that can be reversed (Hunt and Yip 2012; Levant 2014).

Religious voices and institutions have both historically and in contemporary frameworks been at the forefront of legal and social debates about sexual diversity, equality rights, and equal treatment. LGBTQI+ individuals and communities have experienced hostility, violence and expulsion or exclusion from their religious communities and continue to report they experience these negative and violent encounters, across the globe (Gibbs 2015; Rowatt et al. 2009). Religious exemptions to equality provisions in law can also further LGBTQI+ individuals' negative and violent experiences, where their acceptance in law is permitted to be denied based on religious claims. All of this contributes to the persistent and ongoing notions about conflict between religion and sexual diversity. And all spaces which foster violence or harm ought to come under scrutiny, on both social and legal fronts.

While I am not ignoring the ways that religious individuals and groups have acted against (including violence) or been vocally harmful towards LGBTQI+ groups, there is a much more complex relationship between religiosity and sexual diversity than is popularly perceived, a relationship that goes further than that portrayed within media or legal discourse. The destabilization of identity traits 
pioneered by queer studies regarding gender and sexuality and demonstrated through queer theoretical analysis of the ways that gender and sexuality are frequently subjugated and misrepresented can apply in the destabilization of a narrow and misrepresented category of religion (Schippert 2005; Winnubst 2006; Ursic 2014; Young and Shipley 2020).

Religious identity is lived and experienced in much more fluid permutations than are popularly portrayed. The project of queering or querying religion (Comstock and Henking 1997; Taylor and Snowdon 2014; Hunt and Yip 2012) and religious identity has been occurring for several decades, but these complex interweavings of religious identity with other aspects of identity still do not frequently make their way into media coverage of religion and religiosity. Further, when religious identity is part of a legal dispute or a claim for recognition, the legal requirement to define religiosity is such that rigid identity constructs become commonplace in legal narrations (Beaman 2012; Bakht 2007; Sullivan 2018).

Within the Canadian context, religious support for LGBTQI+ communities can be found in numerous spaces, including the Metropolitan Community Church (Toronto), ${ }^{11}$ which opened its doors in 1973 as a new branch of the Universal Fellowship of Metropolitan Community Churches (originating in Los Angeles). Since the Civil Marriage Act (2005), a number of religious organizations have become affirming congregations or have developed inclusive policies to welcome and support members of LGBTQI+ communities to their congregations (Young 2012). The United Church of Canada is probably the best known inclusive religious organization, having publicly stated that it supports same-sex marriage during the debates leading up to the Civil Marriage Act (Nedelsky and Hutchinson 2008; Rayside 2008; Rayside and Wilcox 2012). However, other religious organizations have been formed or have created welcoming spaces that do not receive the same level of public recognition; this includes Salaam Canada, ${ }^{12}$ the Student Christian Movement of Canada, ${ }^{13}$ and New Direction Ministries of Canada. ${ }^{14}$ For many of these organizations, inclusion of the sexually (or racially or ethnically) diverse is a central aspect of religious teaching.

Although inclusive organizations cannot negate the harmful and discriminatory attitudes espoused by religious individuals and groups who oppose equality and marriage rights for the sexually diverse, their activism and engagement across religion and sexual diversity complicates assumptions about an inherently combative relationship between religion and sexual diversity.

While much of the public opposition to equality rights for LGBTQI+ communities has been from religious individuals and particular religious communities, the experience of discrimination in secular and public spaces challenges the assumption that anti-homosexual attitudes are solely religious attitudes. Homophobia and discrimination against LGBTQI+ individuals and communities within secular

\footnotetext{
11 See http://www.mcctoronto.com/.

12 See Salaam Canada, http://www.salaamcanada.org.

13 See Student Christian Movement of Canada, http://scmcanada.org/index.php/about-page/aboutprinciples.

14 See New Direction Ministers of Canada, http://www.newdirection.ca/
} 
spaces is also persistent, ongoing, and frequently not seen to have the same root cause as religious discrimination (Taylor and Peter 2011; Young and Shipley 2020). Studies in high schools have demonstrated that homophobic, biphobic, and transphobic language and attitudes are encountered regularly by LGBTQI+ and non-LGBTQI+ youth, in some instances by their teachers (Taylor and Peter 2011; Short 2013).

Pew's “Global Attitudes Project” highlights diverging attitudes towards homosexuality across forty countries. When asked whether respondents thought that homosexuality was morally unacceptable, morally acceptable, or not a moral issue, responses from Canadians in the survey were as follows: $15 \%$ stated it was morally unacceptable; $30 \%$ stated it was morally acceptable; $50 \%$ stated it was not a moral issue. ${ }^{15}$ Over the last three decades, research on attitudes towards homosexuality and same-sex marriage have continued to demonstrate negative associations, or what is termed homonegativity or homonegativism (Lottes and Grollman 2010), correlated with continued heterosexist attitudes (Neisen 1990).

Research on the effects of internalized homophobia in gay men have included studies on self-harming behaviours as demonstrated by gay men, some of whom "partially construct their identity from elements such as heterosexism and insults targeting gays as feminine, submissive individuals" (Thomas et al. 2014). The stigma experienced by LGBTQI+ communities is witnessed in workplaces and health services (de Bruyn 2004), and in some cases, "the feeling of stigmatization brought by homosexuality pushes them towards negative thoughts and reinforces the feeling of alienation and exclusion" (Thomas et al. 2014, 158). LGBTQI+ seniors report a 'return' to the closet as they move into long-term care facilities; reports of bullying by health care professionals and other seniors in circumstances when they are already vulnerable (Purdon and Palleja 2018). ${ }^{16}$

This increasing research on identity negotiation and identity intersections offers a complex picture of the multiple aspects of the daily lived reality of individuals. Although both religious and sexually diverse identities are frequently essentialized in media and public discourses (in part in response to narrow claims required by legal disputes) (Baron and Epstein 1997), the reality of identity negotiation is much more nuanced. The continued restrictive framing of both religion and sexual diversity places religion as inherently anti-LGBTQI+ and the sexually diverse subject as inherently secular (McGarry 2008). These framings do a disservice to both sides of the identity "debate," and they also problematically ignore the reality of daily discrimination in non-religious spheres.

\section{The Covenant, Campus Culture, and the Law School What Is Your Religious Identity?}

Although it was intended solely as a demographic question at the outset of each interview, the response to the question "With which religion do you most or

\footnotetext{
15 Pew Research “Global Attitudes Project”: http://www.pewglobal.org/2014/04/15/global-morality/ table/homosexuality/.

16 The LGBTQ Aging Project is one example of this: http://www.lgbtagingproject.org/LGBTQ.
} 
exclusively identify?" was, in every interview, a substantive discussion about identity, transformation, and experience. Asking someone to identify their religion might seem on the surface a straightforward question, but for some the answer can be far from simple. Is the question about how one practices day to day (non) religious or spiritual rituals? Is the question about doctrine? Religious authority? And then which religious authority?

Increasingly people seek out multiple reference sources to generate a comprehensive picture of (non)religious and spiritual identities (Beyer and Ramji 2013; Young and Shipley 2020; Yip and Page 2013; Ursic 2014); identifying as Catholic does not indicate agreement or acquiescence with all Catholic teachings, beliefs, practices, or behaviours. It can refer to familial relationships, church community, attendance at particular times of year or services. It is always contextualized.

Within some national contexts, the "rise of the nones" is also an important part of the landscape of ideological, ethical, and value-driven identity categories-with the inclusion of No Religion on national surveys across multiple countries, we see a rapid increase in people identifying as non-religious (Wallis 2014; Woodhead 2013). What is not yet generated from an analysis of the data is why people are choosing that category more-is it simply because it wasn't an option before and now it is? Is it more socially acceptable to declare a non-religious identity than it was in the past? The relationship between non-religiosity and sexual diversity is also beginning to be explored. Research has pointed us towards LGBTQI+ and gender diverse individuals who leave religious organizations where they experience discrimination (Siraj 2012; Cragun and Sumerau 2014, among others). However, we are just at the beginning of uncovering the depth of value and ideology that is embedded in ticking the "Non-religious" box (Young and Shipley 2015; Wallis 2014; Woodhead 2013).

In the case of the participants in this project, the complexity of the question about religious identity is compounded by their experiences specific to their sexual identities as perpetrated by their religious communities-both at Trinity Western and in their home churches. When asked how they identified their religion, none of the participants in this project identified as evangelical: $40 \%$ identified as agnostic, $10 \%$ as protestant (but no longer evangelical), $10 \%$ said they do not identify with religion now, though they were born and raised Christian, 20\% identified as spiritual, of whom $10 \%$ said no longer Christian but spiritual, and $10 \%$ said religiously confused but spiritually curious.

It is significant that all of them indicated that their religious identities have been marked by their experiences at Trinity Western and by the evangelical community.

I was reaching a point where I was basically at the crux of my jump from Christian to Agnostic Christian when I recognized my own same sex attraction as a bisexual, which is something I had been in denial about for a really long time, and it kind of hit me that I realized there is a really good chance that I could fall in love with another man and have the most genuinely healthy holy relationship with him, but the community of religion that I had at that moment did not view that as something healthy or holy. (David) 
Describing his disconnection from the Christian community, aesthetically as well as theologically, David looks to building up a theology and practice that reflect the respect and acknowledgement he feels the LGBTQI+ community deserves, finally stating, "I am happy to actualize most of my religion outside of the church at this point, if that makes sense."

For still others, the religion question is complicated because of a sense of disillusionment with Trinity Western. Valerie no longer considers herself evangelical because of her time at Trinity Western; Cameron said he felt as though he were a member of the evangelical community while at Trinity, but no longer identifies as Christian: "I almost am on the side of being agnostic. And I will just leave it at that for now."

These patterns of religious identity shifting away from Trinity Western have been present in all interviews to date. It is significant to note that the experiences participants had or witnessed at Trinity Western, as LGBTQI+ identified individuals or queer allies, impacted their sense of disconnection from the evangelical tradition and, for some, religion altogether.

\section{Why Do Queer Students Even Go to Trinity?}

A recurring theme, both in terms of the response to the controversy itself and also as discussed by the interview participants as to the Covenant and campus culture, is framed around the question: Why do LGBTQI+ students ${ }^{17}$ go to Trinity Western University in the first place? The question itself (harkening to the statement from the 2001 legal decision) presumes that the relationship between religion and LGBTQI+ is predetermined as one of conflict. It also ignores the ways individuals come into, negotiate, and construct their identities. And it implicitly gives permission to dictates such as the Covenant to remain unchanged, regardless of their impact on the LGBTQI+ community, because it suggests that the answer to the question is for LGBTQI+ students to simply go elsewhere.

One of the responses participants in this study gave (and indeed, external community members also on the receiving end of this question) is that it doesn't matter why queer students are at Trinity Western-the fact is they are there (Matthew). The question in and of itself ignores the current experiences of queer students on campus. Furthermore, the reasons people choose their post-secondary institution vary widely and are not necessarily connected to institutional ideology.

Participants' responses to this question when it has arisen in social or educational spaces have been: Does it matter why LGBTQI+ students go to Trinity Western? Do they negate their right to self-expression, to reporting harassment, to being themselves because they are students at Trinity?

The implications of the question itself point to complicated relationships with both religion and sexual diversity. Many participants describe being closeted while at Trinity Western, hiding their same-sex sexual attractions and relationships (Matthew; Megan; Lorraine; Michael). Three described themselves as self-hating

17 The experiences of LGBTQI+ faculty and staff have not been the focus of the debate about the law school, though their experiences also warrant significant attention. 
and openly homophobic for part of or the full duration of their time at Trinity Western (Michael; David; Megan). Others feel guilt for their ability to "straight pass"-pass as straight because they are bisexual or not seen as "obviously" part of the queer community (Isabelle).

I think it was in 2014 that I kind of, um, came out to myself, and to my councillor, and then I came out to my church; through a conversation with the pastor, I decided that I couldn't live, like, a gay lifestyle, and be a Christian. I kind of had to choose between the two, and, at that point I kind of picked, like I left my church and abandoned that part of my identity, and kind of started to explore my sexuality more. (Michael)

[A]s much as, like, I struggle politically with the term Christian, reconciling my faith [and] my sexuality was still something really huge for me.... I mean I definitely wouldn't completely leave Christianity over my sexuality, right. So like, both are equally important to me and on one hand everyone is like "oh well, the public is so accepting," it's like well, they're accepting of LGBT people as long as they fit a certain type, as long as they are secular to a certain extent. But I honestly dream for equality for all people regardless of sexual orientation or gender identity [and] part of that is saying, "well, you have access to the religion you see fit, no less than someone who is heterosexual" so I actually think that fighting for a place for queer students at Trinity is extremely important to an overall-I hate using the word agenda, but-I guess agenda for LGBTQ equality. So that is my answer to that question, cause I get asked it, like why did you go there? It's like cause I wanted to. (Matthew)

As a bisexual person who is in a heterosexual partnership right now, I think I don't always feel like my experience is generalizable because, as much as I hate the idea of straight passing and the idea that like I'm less part of the LGBTQ community because I have a heterosexual partner, I think it has given me a bit of a façade, and a bit of safety that isn't given to students that are openly gay or openly lesbian on campus, and I think when you talk to other students they will feel that they had no option but to be public about it. I think my own experience has been struggling with the fact that I don't look like a member of the LGBTQ community from the outside, but I think that that isn't necessarily a positive. It's made me struggle more with how up front should I be with my identity, how willing should I be to talk about it, how willing should I be to even talk to my partner as a bisexual male about how he feels about talking about his identity. (Isabelle)

Lorraine talks about how isolating the campus community was when she was at Trinity Western; her one close friend was also gay but she didn't come out to him during school, and he didn't come out to her. She says she always thought he was "like me" but that it wasn't until they graduated that they actually spoke about being queer.

The guilt and shame participants felt for doing something considered "immoral," in their view of Trinity Western's teachings and community, led to depression and anxiety in some cases and self-medicating with alcohol in others and contributed to the disconnect from the evangelical community that they experienced. Young adult identity construction and negotiation are deeply engaged 


\section{Heather Shipley}

and thoughtful. Developing one's own sense of identity, drawn from familial, social, religious, and media influences, is frequently at its peak during university (Young and Shipley 2020; Yip and Page 2013). Identity formation as experienced by the study participants involved negating their identity in the face of institutional-and potentially social-consequences. This critical process is clearly halted for individuals who are LGBTQI+ at Trinity Western.

\section{Community Covenant and Campus Culture: Sexual Victimization}

By far the most unexpected finding from the interviews was a concern that participants raised beyond the impact and experience of discrimination based on sexual diversity. The predominant concern that participants raised about the effect of the Covenant on students was the inability of queer students to report experiences of same-sex sexual violence at Trinity Western. Campus sexual violence is a pervasive and prevalent issue across Canada (and beyond); the Covenant exacerbates the issue, according to participants, because in addition to all the other reasons individuals may resist reporting issues of sexual violence (Jones et al. 2009), members of the queer community both fear retribution from the university for violating the Covenant and do not have a "safe" space they can go to actually submit a report. There is no mechanism to support survivors of sexual violence in same-sex circumstances.

Throughout the interviews, participants pointed to harms beyond the scope of my initial interview questions that result from the Covenant-related to LGBTQI+ issues as connected with sexual assault and rape. While none of the participants indicated or reported that they were sexually assaulted or raped during their time at Trinity Western, the concern about rape is prevalent. LGBTQI+ students (and faculty/staff) do not have anywhere to report sexual harassment or sexual violence in same-sex situations and further are afraid to disclose instances of sexual violence in such situations, fearing reprisal for violating the Covenant.

Participants indicated that the issue of rape culture among the heterosexual population is problematic enough, also imbued with fear of punishment if the student has engaged in a relationship outside marriage, has consumed alcohol, or is seen to be engaging in "immoral" behaviours. These fears are added to the fears that are expressed by individuals at universities across Canada-the trauma of reporting, feeling of being revictimized through the system, and concern about being blamed for the act itself. The Covenant, and the culture it supports, compounds the issues of campus sexual violence for students who engage in any kind of sexual relationship outside marriage; in the case of LGBTQI+ sexual violence, the impacts are even higher. LGBTQI+ students do not feel safe identifying as nonheterosexual; having to first expose their sexual identity and then an experience of same-sex sexual violence when Trinity Western offers no mechanisms of support for either is seen as doing enormous harm to the queer community.

I think how Trinity handles sexuality overall, not just for students who don't identify as heterosexual, but the way that they approach the issue of sex in general is pretty bad. I know that there have been issues of sexual assault on campus, and there have been issues with people not taking birth control that 
they need for unrelated medical issues at Trinity.... I think the way that they treat sexuality in general facilitates a very tight lipped and fearful conversation. I think that impacts students across campus negatively. I think it has the effect of not only enforcing a dangerous code of silence on sexual assault, but I think it also has the effect of reinforcing ideas of rape culture and ... ideas of gender expression that are not healthy and [can] silence particular viewpoints. And Trinity has kind of said it doesn't matter what you believe as long as you don't do xyz. It seems legalistic to me, but also it does not seem practical-from a cultural basis, I can abstain on campus but have a total potty mouth and perpetuate this sexually perverse or whatever culture on campus verbally and I would not get reprimanded at all. (Isabelle)

[S] sexual assault... is a huge issue and I know that [a professor] at the university has been charged with writing a sexual assault policy, which is a little bit laughable because the Covenant in its essence makes it impossible to create a good sexual assault policy in my view. I think as long as shame remains a centre of sexuality, as I think the Covenant promotes, you are not going to be able to deal with sexual assault. How do you enable someone to report these things while you shame them at the same time? I think a good sexual assault policy will be counter to the covenant. And as someone who has experienced those types of things, I would never report that to Trinity for a million and one reasons. (Valerie)

This issue has been raised in relation to other faith-based institutions with Covenants similar to Trinity Western's. A study at Brigham Young University also points to the fear of punitive action for students who report rape (saying that victims are punished for engaging in "sinful" behaviours) (Fletcher and Alberty 2016). While much of the focus on the Covenant in the debate about the law school (and previously as connected to the education program) has expressed concern about discrimination based on sexual orientation and sexual diversity, participants continue to reference concerns and issues faced by students on campus because of the "Covenant culture"-which is the culture of attitudes towards these issues, as generated by the Covenant, which do not simply disappear if the Covenant is changed or discarded.

This is again not an issue confined to Trinity Western, however, and is present in other faith-based institutions that require a signed covenant, such as Brigham Young. While victims of sexual violence are already reluctant to report their experiences-because of factors such as shame, embarrassment, fear of exposure, fear of reprisal, feeling that they will not be believed or taken seriously-compounding those fears is the concern of punitive measures because of the signed Covenant.

\section{Win or Lose, Queer Students Will Lose}

Finally, when asked how they see this playing out-beyond the Supreme Court of Canada's ruling-they all agreed that regardless of the SCC decisions, queer students will lose. The interviews were conducted before the decisions were rendered, so participants were framing their responses without knowing the outcome. And they stated that queer students would lose either because the SCC 
upheld the Covenant and the law school or they would lose because the SCC decided in favour of the law societies. They feared that queer students, including those engaged in OneTWU, would be blamed for the losses at Trinity Westernfinancial, legal, and public.

As Matthew states:

I have always said this from the beginning, [that] any organizing efforts around feminism or gay rights at Trinity [have] to be independent from the law school, because on one hand, winning or losing the law school can really shift the public discourse, but in terms of actual experiences, those have always been, and will continue to be, until we see an overhaul of administration, independent of whatever the administration does. So that in some ways consolidates any result, because it's like "we are just going to continue what we've always done.” The part that worries me is that it's not Trinity vs. the law society, it's Trinity vs. the gays, and I think there is a slippage there ..., and it's pretty dangerous because, if Trinity loses, and I do believe they will lose, despite my lacking legal analytical skills, it could turn out very poorly for gay students on campus. It could suddenly be this is One TWU's fault. If people didn't talk to the media, if people didn't organize we wouldn't have had this problem.

Although Trinity Western has now stated that students will not have to sign the Covenant, the long-term concern expressed by participants (most of whom are now graduates) is that the environment for queer students on campus does not get better until the culture on campus changes. They do not imagine the outcome being favourable unless there is a complete campus culture change; it is not just about the Covenant, as they stated above, it's about the culture that has been created by the administration to advance the legal fight for the law school. As Matthew stated, there has been no change to the Covenant, there is only a change in the requirement to sign it. LGBTQI+ students will continue to experience harm on campus until issues that face the queer community are addressed-including fear of identifying oneself and having no safe space to be themselves.

\section{The Law School}

While most of the participants said that they do not think that students from the law program would necessarily hold discriminatory attitudes, they continue to point to all the religious and LGBQTI+ students whose voices are being silenced in the "fight for religious freedom." "Whose religious freedom are you actually fighting for?" (Daniel)

I think overall, generally, I have been trying to tell people this stopped being about the Covenant a long time ago, and about the law school. I think it is about a greater pattern of institutional ignorance and a pattern of harm embedded in the university's culture, and I think they could change the Covenant today and no one would be happy and people would still be getting hurt, and I think there are deeper issues at Trinity than just whether or not you can have sex. (Daniel)

The narratives that have been given to these students, some of whom came out during their time at Trinity and were encouraged to see their sexuality as a 
symptom, were recommended to conversion therapy, or were told they could actively suppress or change their sexuality through behaviour, are narratives that (among other things) have served to silence the voices of the LGBTQI+ community. The battle that has been fought on campus has been around much longer than the controversy over the law school or the more recent debates about the Covenant. Whose religion counts as "real" religion on campus and where do the voices of those who are religious and LGBTQI+ or religious and allies of the LGBTQI+ community fit in the narrative of religious freedom that has been presented by Trinity Western's administration? As argued by Young (2015) regarding young people and religious identity, who speaks for religion?

The narrowing of identity in public and legal debates is fed by multiple problematic sources. Law's requirement to present identity within constraints is one part of the problem. Another issue is the voices and experiences that are frequently overlooked in litigation strategies. Queer identities and the queering of identity in public and social spaces is a project that seeks to challenge assumptions about gender and sexuality. However, limitations continue to be imposed as sexual orientation equality rights are seen to be more readily attained for gay and lesbian individuals than for trans, intersex, or non-binary individuals (Irving and Raj 2014; Duggan 2002; Halberstam 1998; Kinsman 2006). Same-sex marriage challenged the heteronormative boundaries of marriage and family. But it retained its monogamous structures (Calder and Beaman 2014). Demonstrated by the voices highlighted in this article, there is much work still to be done to consider how LGBTQI+ students and allies experience their environment, with or without a Community Covenant.

\section{Conclusion}

While the initial goals of this project were to explore the ways that the law school controversy was playing out in experiences among LGBTQI+ students at Trinity Western and to see how the public debate was impacting their identity formation, what the project has ultimately uncovered is a set of deep concerns related to violence, harm, and ongoing negative experiences that are permitted through the lens of a Covenant (which produces the fear of retribution) but are enabled by campus culture. The concerns that were expressed by participants about sexual violence across all sexual identities, made worse for members of the LGBQTI+ communities, emphasize the need to address both the campus culture and the Covenant itself. Campus sexual violence is a concern across all colleges and universities in Canada, with some provinces mandating new sexual violence policies and resources (see for example Ontario Regulation 131/16). Trinity Western's Covenant and push to maintain its boundaries as a right to religious freedom exacerbates an ongoing and pervasive issue across Canada. LGBTQI+ students risk exposure (and fear reprisal) for disclosing the experience of same-sex sexual violence. Further, there are no supports in place for those students-either resources or reporting mechanisms - to encompass same-sex sexual engagements.

In the midst of a larger national context about diversity and inclusion across educational and professional spaces, the defense of the Covenant places itself at 
odds with both public and private sector pushes to facilitate welcoming and inclusive spaces. It also continues the problematic, and inaccurate, narrative that religion and sexual diversity are incompatible identity markers. Continuing to defend the Covenant, even with changing the signing provision, in the face of the harms and concerns expressed by members of the Trinity Western community places Trinity Western administration at odds with many of its own community members, who are sexually diverse or allies and want the space to reflect those values as part of the evangelical belief system.

Religion's relationship to sexual diversity as complicated and nuanced, and not solely one of contention, is much less popularly represented or understood, for exemple in law and media. Although the majority of cases involving sexual orientation as disadvantaged or discriminated against in policy do not also involve religious freedom (Shipley 2015), the relationship between religious freedom and sexual orientation equality rights is frequently perceived to be inherently oppositional, with cases regarding the two categories in conflict being over represented as the fundamental relationship. Religious organizations and individuals have provided support and acceptance, in some instances decades in advance of public, secular support and acceptance; individuals who identify across religious and LGBTQI+ identities report that much of the tension is externally imposed (Taylor and Snowdon 2014; Young and Shipley 2015).

The experience of discrimination against LGBTQI+ individuals and communities transcends religious and secular spheres. It exists across spaces regardless of religious identity (or lack thereof). The frequent assumption that the location of harm towards LGBTQI+ communities is "known" and is found within religious spheres and religious institutions problematically ignores the ongoing experience of discrimination across secular, public spaces. An examination of the ways that anti-LGBTQI+ attitudes persist (and are permitted in some secular spheres) regardless of religious/ non-religious beliefs is required to target ongoing experiences of harm across spaces.

The controversy surrounding the law school and Covenant at Trinity Western provides an opportunity to consider inclusivity and non-discrimination across all law schools, to assess the experiences of both LGBTQI+ and religious students (and, of course, those who occupy both identities), and to ensure those experiences align with Charter and human rights policies and protections. Continually pitting religion and sexuality (sexual diversity) against one another ignores the relationship of religion to sexual diversity and vice versa, doing a disservice to both.

Although the dominant representation of religion's role as it relates to equality rights for LGBTQI+ communities is one of opposition (resistance) to these equality rights, it is evident in listening to the voices of those seldom heard in these debates that the representation is inaccurate and ignores the ways individuals on both sides of the debate very carefully consider the issues before reaching a decision. This includes the way members of the various law societies ultimately voted regarding accreditation for the law school at Trinity Western; an individual who has voted against accreditation does not necessarily assume religion is the problem or that religion and sexual diversity are incompatible. Further, simply being at Trinity Western University does not equate to agreeing with all university policy or to possessing anti-homosexual attitudes. 
Although these complex understandings are widespread, the representation of the issues is dominated by a small group of individuals on both sides of the debate and they are subsequently generalized to represent more broadly the attitudes of people who are either for or against the law school. I do not have a solution as to how we create better dialogue within the public sphere about controversies such as the debate about Trinity Western's law school and Community Covenant. It is clear that a more nuanced dialogue is already happening on the ground across multiple spaces, but these nuanced and complex discussions are not being represented in the broader arguments about the law school. Instead, overgeneralizations about proponents and opponents persist and, as I have argued, draw public attention to certain specific spaces of discrimination (or possible discrimination) against LGBTQI+ communities, harmfully and problematically ignoring the pervasive reality of discrimination against LGBTQI+ communities beyond religious and secular divides.

\section{References}

Arweck, Elisabeth, and Eleanor Nesbitt. 2011. "Religious Education in the Experience of Young People from Mixed-Faith Families.” British Journal of Religious Education 33, no. 1: 31-45.

Aune, Kristin, Sonya Sharma, and Giselle Vincett, eds. 2008. Women and Religion in the West: Challenging Secularization. Aldershot: Ashgate.

Avishai, Orit. 2008. “'Doing Religion' In a Secular World: Women in conservative religions and the question of agency." Gender \& Society 22, no. 4: 409-33.

Bakht, Natasha. 2007. "Religious Arbitration in Canada: Protecting women by protecting them from religion." Canadian Journal of Women and the Law 19:119-44.

Baron, Jane B., and Julia Epstein. 1997. “Is Law Narrative?” Buffalo Law Review 45:141-87.

Beaman, Lori G. 2012. "Battles over Symbols: The 'religion' of the minority versus the 'culture' of the majority." Journal of Law and Religion 28:67-104.

Berger, Benjamin. 2015. Law's Religion: Religious Difference and the Claims of Constitutionalism. Toronto: University of Toronto Press.

Beyer, Peter. 2008. "From Far and Wide: Canadian religious and cultural diversity in global/ local context." In Religion and Diversity in Canada, ed. Lori G. Beaman and Peter Beyer, 9-40. Leiden: Brill Academic Press.

Beyer, Peter, and Rubina Ramji, eds. 2013. Growing up Canadian: Muslims, Hindus, Buddhists. Montreal: McGill-Queen's University Press.

Bramadat, Paul, and David Seljak. 2008. Christianity and Ethnicity in Canada. Toronto: University of Toronto Press.

Bussey, Barry W. 2018. "TWU Loses: Canada's religious freedom forever altered." Canadian Council of Christian Charities, June 15. https://www.cccc.org/news_blogs/barry/2018/06/15/ twu-loses-canadas-religious-freedom-forever-altered/ (accessed August 15, 2018).

Calder, Gillian, and Lori G. Beaman. 2014. Polygamy's Rights and Wrongs: Perspectives on harm, family, and law. Vancouver: UBC Press.

Community Covenant, Trinity Western University. http://twu.ca/studenthandbook/univer sity-policies/community-covenant-agreement.html.

Comstock, Gary D., and Susan Henking, eds, 1997. Que(e)rying Religion: A critical anthology. New York: Bloomsbury.

Cragun, Ryan, and J. Edward Sumerau. 2014. "The Last Bastion of Sexual and Gender Prejudice? Sexualities, race, gender, religiosity, and spirituality in the examination of 
prejudice toward sexual and gender minorities." The Journal of Sex Research 52, no. 7: 821-34.

Craig, Elaine. 2013. "The Case for the Federation of Law Societies Rejecting Trinity Western University's Proposed Law Degree Program." Canadian Journal of Women and Law 25, no. 1: 148-70.

Crenshaw, Kimberlé. 2014. On Intersectionality: The essential writings of Kimberlé Crenshaw. New York: The New Press.

_ 1991. "Mapping the Margins: Intersectionality, identity politics, and violence against women of color." Stanford Law Review 43:1241-99.

Davie, Grace. 2014. Religion in Britain: A persistent paradox, 2nd Edition. London: John Wiley \& Sons.

Day, Abby, Gisele Vincett, and Christopher R. Cotter, eds, 2013. Social Identities Between the Sacred and the Secular. Farnham: Ashgate.

de Bruyn, Theodore. 2004. "A plan of action for Canada to reduce HIV/AIDS-related stigma and discrimination." Canadian HIV/AIDS Legal Network. http://www.aidslaw.ca/ publications/interfaces/downloadFile.php?ref=48

Dueck, Lorna. 2018. “Trinity Western Decision is a Big Loss for Christian Freedom,” The Globe and Mail, June 17, https://www.theglobeandmail.com/opinion/article-trinitywestern-decision-is-a-big-loss-for-christian-freedom/ (accessed 27 May 2019).

Duggan, Lisa. 2002. "The New Homonormativity: The sexual politics of neoliberalism.” In Materializing Democracy: Toward a Revitalized Cultural Politics, ed. R. Castronovo and D. D. Nelson, 175-94. Durham: Duke University Press.

Ehrman, Bart D. 2003. Lost Christianities: The battles for scripture and the faiths we never knew. Oxford: Oxford University Press.

Emon, Anver. 2013. "The Paradox of Equality and the Politics of Difference: Gender equality, Islamic law and the modern Muslim state." In Gender and Equality in Islamic Law: Justice and ethics in the Islamic legal tradition, ed. Ziba Mir-Hosseini, 237-53. London: IB Tauris.

Fletcher, Peggy Stack, and Erin Alberty. 2016. "How Outdated Mormon Teachings May Be Aiding and Betting 'Rape Culture," The Salt Lake Tribune, May 6, https://www.sltrib. com/religion/local/2017/07/27/how-outdated-mormon-teachings-may-be-aiding-andabetting-rape-culture/.

Gibbs, Jeremy. 2015. "Religious Conflict, Sexual Identity, and Suicidal Behaviors among LGBT Young Adults." Archives of Suicide Research 19, no. 4: 472-88.

Halberstam, J. 1998. Female Masculinity. Durham: Duke University Press.

Hoover, Stewart. 2006. Religion in the Media Age. London: Routledge.

Hunt, Stephen, and Andrew Kam-Tuck Yip, eds. 2012. The Ashgate Research Companion to Contemporary Religion and Sexuality. Farnham: Ashgate.

Irving, Dan, and Rupert Raj. 2014. Trans Activism in Canada: A Reader. Toronto: Canadian Scholar's Press.

Johnson, Rebecca. 2007. “Judging Magic: Can you see the sleight of hand?" Michigan Law Review 105, no. 6: 1353-66.

Jones, Jeffrey, Carmen Alexander, Barbara Wynn, Linda Rossman, and Chris Dunnuck. 2009. "Why Women Don't report Sexual Assault to the Police: The influence of psychosocial variables and traumatic injury." The Journal of Emergency Medicine 36, no. 4: 417-24.

Kinsman, Gary. 2006. "Mapping Social Relations of Struggle: Activism, ethnography, social organization." In Sociology for Changing the World: Social Movements/Social Research, ed. Caelie Frampton, Gary Kinsman, A. K. Thompson, and Kate Tilleczek, 133-56. Black Point, N.S.; Winnipeg: Fernwood. 
Kislowicz, Howard. 2016. "Developments in Religious Freedom: What Saguenay and Loyola tell us-and don't-about the Trinity Western University law school case." Supreme Court of Canada Law Review 71:75-95.

Knott, Kim, Elizabeth Poole, and Teemu Taira. 2013. Media Portrayals of Religion and the Secular Sacred. London: Ashgate.

Lefebvre, Solange, and Lori G. Beaman. 2014. Religion in the Public Sphere: Canadian case studies. Montreal: McGill-Queen's University Press.

Levant, Ezra. 2014. "Ban on Christian Values," http://www.ezralevant.com/ban-on-chris tian-values/.

Lottes, Ilsa L., and Eric Anthony Grollman. 2010. "Conceptualization and Assessment of Homonegativity.” International Journal of Sexual Health 22:219-33.

Mathen, Carissima. 2008. "Choices and Controversy: Judicial appointments in Canada." University of New Brunswick Law Journal 58:52-72.

Mathen, Carissima, and Michael Plaxton. 2014. "Legal Education, Religious and Secular: TWU and beyond," SSRN Working Paper Series, http://ssrn.com/abstract=2428207.

McGarry, Molly. 2008. “'The Quick, the Dead and the Yet Unborn': Untimely sexualities and secular hauntings." In Secularisms, ed. Janet R. Jakobsen and Ann Pellegrini, 247-78. Durham and London: Duke University Press.

McGuire, Meredith. 2008. Lived Religion: Faith and practice in everyday life. Oxford: Oxford University Press.

Moon, Richard. 2012. "Freedom of Religion Under the Charter of Rights: The limits of state neutrality." University of British Columbia Law Review 45:497-549.

Nedelsky, Jennifer, and Roger Hutchinson. 2008. "Clashes of Principle and the Possibility of Dialogue: A case study of same-sex marriage in the United Church of Canada." In Law and Religious Pluralism in Canada, ed. Richard Moon, 41-64. Vancouver: UBC Press.

Neisen, Joseph H. 1990. "Heterosexism: Redefining homophobia for the 1990s." Journal of Gay \& Lesbian Psychotherapy 1:21-35.

Newman, Dwight. 2013. "On the Trinity Western University Controversy: An argument for a Christian law school in Canada." Constitutional Forum 22, no. 3: 1-14.

Ontario Regulation 131/16: Sexual Violence at Colleges and Universities: https://www. ontario.ca/laws/regulation/160131.

Purdon, Nick, and Leonardo Palleja. 2018. "We're Going Back into the Closet': LGBTQ seniors way of being 'out' in long-term care facilities." June $28, C B C$ News, https://www.cbc.ca/ news/canada/lgbtq-seniors-long-term-care-homes-discrimination-1.4721384 (accessed 17 August 2018).

Rayside, David. 2008. Queer Inclusions, Continental Divisions: Public recognition of sexual diversity in Canada and the United States. Toronto: University of Toronto Press.

Rayside, David, and Clyde Wilcox. 2012. Faith, Politics, and Sexual Diversity in Canada and the United States. Vancouver: UBC Press.

Ritivoi, Andreea Deciu. 2009. "Explaining People: Narrative and the study of identity." StoryWorlds: Journal of Narrative Studies 1:25-41.

Rowatt WC, LaBouff J, Johnson M, Froese P, Tsang J. 2009. “Associations among religiousness, social attitudes, and prejudice in a national sample of American adults." Psychology of Religion and Spirituality. 1:14-24.

Schippert, Claudia. 2005. "Queer Theory and the Study of Religion." Revista de Estudos da Religião 4:66-84.

Shipley, Heather. 2015. "Religious Freedom and Sexual Orientation: Equality jurisprudence and intersecting identities." Canadian Journal of Women and Law 27, no. 2: 92-127. 
. 2014a. "Globalization, Religion and Sexuality: Plus ça change?” Estudos de Religião, Special Journal Issue "Religion and Globalization," ed. Cristina Maria de Castro 28, no. 2: 74-101.

- 2014b. "Religious and Sexual Orientation Intersections in Education and Media: A Canadian perspective," Sexualities, Special Journal Issue "Sexuality and Religion," ed. Ria Snowdon and Yvette Taylor 17, no. 5/6: 512-28.

Short, Donn. 2013. "Don't be so gay!": Queers, bullying, and making schools safe. Vancouver: UBC Press.

Siraj, Asifa. 2012. “'I Don't Want to Taint the Name of Islam': The influence of religion on the lives of Muslim lesbians," Journal of Lesbian Studies 16, no. 4:449-67.

Søndergaard, Dorte M. 2012. "Bullying and Social Exclusion Anxiety in Schools." British Journal of the Sociology of Education 33:355-72.

Stueck, Wendy. 2018. “B.C.'s Trinity Western University Drops Mandatory Covenant Forbidding Sex Outside Heterosexual Marriage," The Globe and Mail, August 14, https:// www.theglobeandmail.com/canada/british-columbia/article-bcs-trinity-western-univer sity-drops-mandatory-covenant-forbidding/ (accessed August 15, 2018).

Sullivan, Winnifred. 2018. The Impossibility of Religious Freedom, New Edition. Princeton: Princeton University Press.

Taylor, Catherine G., and Tracey Peter, with T. L. McMinn, T. Elliott, S. Beldom, Z. Gross, S. Paquin, and K. Schachter. 2011. Every Class in Every School: Final report on the first national climate survey on homophobia, biphobia, and transphobia in Canadian schools. Toronto: Egale Canada Human Rights Trust.

Taylor, Yvette, and Ria Snowdon, eds. 2014. Queering Religion, Religious Queers. London: Routledge.

Thomas, Francois, Marie Cozette Mience, Joanic Masson, and Arnal Bernoussi. 2014. "Unprotected Sex and Internalized Homophobia." The Journal of Men's Studies 22:155.

Ursic, Elizabeth. 2014. "Bi the Way: Rethinking the categories of religious identity." The International Journal of Religion and Spirituality in Society 3, no. 4: 29-34.

Wallis, Simeon. 2014. “Ticking 'No Religion': A case study amongst 'young nones.” DISKUS: The Journal of the British Association for the Study of Religions 16, no. 2: 70-87.

Winnubst, Shannon. 2006. Queering Freedom. Indianapolis: Indiana University Press.

Woodhead, Linda. 2013. "Liberal Religion and Illiberal Secularism.” In Religion in a Liberal State, ed. Gavin D'Costa, Malcolm Evans, Tariq Modood, and Julian Rivers, 93-116. Cambridge: Cambridge University Press.

Woodhead, Linda, Paul Heelas, and Benjamin Seel. 2005. The Spiritual Revolution: Why Religion is Giving Way to Spirituality. London: Wiley-Blackwell.

Yip, Andrew Kam-Tuck, and Sarah-Jane Page. 2013. Religious and Sexual Identities: A Multi-Faith Exploration. London: Routledge.

Young, Pamela Dickey, 2012. Religion, Sex and Politics: Christian churches and same-sex marriage in Canada. Winnipeg: Fernwood Publishing.

Young, Pamela Dickey, and Heather Shipley. 2020. Identities Under Construction: Religion, gender and sexuality among youth in Canada. Montreal: McGill-Queen's University Press, under review.

- 2015. "Belief, Not Religion: Youth negotiations of religious identity in Canada." In Handbook of Children and Youth Studies, ed. Johanna Wyn and Helen Cahill, 861-73. London: Springer.

Young, Pamela Dickey. 2015. “Who Speaks for Religion?” In Issues in Religion and Education: Whose Religion?, ed. Lori G. Beaman and Leo Van Arragon, 305-20. Leiden: Brill Academic Press. 


\section{Cases Cited}

Alberta v Hutterian Brethren of Wilson Colony, 2009 SCC 37, [2009] 2 S.C.R. 567

Law Society of British Columbia v. Trinity Western University, 2018 SCC 32.

$R v$ N.S., 2012 SCC 72

Saskatchewan (Human Rights Commission) $v$ Whatcott, 2013 SCC 11

Trinity Western University v British Columbia College of Teachers, [2001] 1 S.C.R. 772, 2001 SCC 31.

Trinity Western University v. Law Society of Upper Canada, 2018 SCC 33.

Heather Shipley

Project Manager

Classics and Religious Studies, University of Ottawa

hshipley@uottawa.ca 